\title{
The Effect of Supply Chain Management Practice on Organizational Performance in Case of Shemu Soap and Detergent P.L.C, Dire Dawa
}

\author{
Mikiyas Birahanu \\ College of Business and Economics, Dire Dawa University, Ethiopia \\ Girmay Aklilu \\ College of Business and Economics, Dire Dawa University, Ethiopia
}

\begin{abstract}
The purpose of this paper is to examine the effect of supply chain management practice on organizational performance in the context of shemu soap and detergent factory p.l.c. Data were collected from 80 employees using closed ended questionnaires and analyzed using the 'descriptive statistics and correlation and ordinal logistic regression' methods. Analysis of the result revealed that the supply chain management practice (strategic supplier partnership, customer relationship, level of information sharing and quality of information sharing and internal lean practice) and organizational performance is causally correlated. Thus, the contribution of this study for academics and practitioners is that supply chain management practices will affect organizational performance as measured by supply chain management practice elements i.e. strategic supplier partnership, customer relationship, level of information sharing and quality of information sharing and internal lean practice.
\end{abstract}

Keywords: supply chain management practice, shemu soap and detergent factory, organizational performance

DOI: $10.7176 /$ IEL/10-4-02

Publication date:May $31^{\text {st }} 2021$

\section{Introduction}

\subsection{Background of the Study}

Over the years, the character of competition has changed to the degree that companies no longer compete with the other companies on the basis of quality as traditionally experienced in the 1980s (Fawcett et al. 2007). However, the new basis of competition lies outside the walls of organizations, and is determined by how effectively companies tie their operations with their supply chain partners such as suppliers, distributors, wholesalers, retailers and end customers (Mamun, 2011). A Supply Chain can be described as a network connecting different entities, from the customer to the supplier, through manufacturing and services, so that the flow of materials, money and information can be effectively managed to meet the business requirements (Zigiaris, 2000). Increased competition in today's international markets, the introduction of products with shorter life cycles, and the heightened expectations of customers have forced business enterprises to invest in, and focus attention on, their supply chains (Christopher \&Towill, 2000). Generally, from the literature review it is clear that researchers have varies views on the supply chain management practices that are fundamental to organizational performance. It is an indication that different organizations rank these practices differently whereby one supply chain management practice can be widely adopted by an organization but minimally adopted or even not at all used by another organization. However, the relationship of supply chain management with performance cannot be regarded as conclusive (Cousins, et al., 2006). The researcher had scarcely found any prior studies which were specifically conducted to study the practical implementation of supply chain management practices as well as their impact on the organizational performance in Ethiopia soap industry.

Thus, the purpose of this research paper is to examine the effect that supply chain management practice has on organizational performance in case of Shemu soap and detergent factories

\subsection{Statement of the Problem}

The world is in the era of supply chain competition, where organization no longer acts in isolation as an independent entity, but as a supply chain to create value delivery systems that are more responsive to fastchanging markets, more consistent and dependable (Christopher, 2005, Pandey and Gaug, 2009). Supply Chain Management practice in Ethiopia is still in the infancy stages, there are small numbers of manufacturing companies integrating it to their organizational system. In addition, there are some challenges in the industry which resulted in reducing the quality and demand of products manufactured locally. One of the problems is poor supply chain management practice of organizations in the industry (Hailemichael, 2011).

But there are various problems that affect supply chain management challenges affect supply chain by affecting one or more of its components. These component are either internal or external to the supply chain and can be classified as belonging to the following realms or the contributors to the functioning on the supply chain; 
transportation, utilities/equipment, communication, suppliers, customers, labor and finance (stecke and kumar, 2007).

Different researcher conduct academic studies on supply chain management practice for instance, Vincent K. Kiprop(2015), conducted study on impact of supply chain management practices on the performance of banks in Kenya. This research conceptualizes and develops four dimensions of SCM practice; outsourcing of goods \& services, information \& communication technology, strategic supplier partnership, and globalization. But, it fails to incorporate the supply chain management practice dimensions like level of information sharing, quality of information sharing, customer relation and internal lean practice.

Makena (2014) conducted a study on Impact of Supply Chain Management Practices on Organizational Performance: A Case Study of Haco Industries Limited (Kenya). It fails to incorporate the level of information sharing, quality of information sharing and internal lean practice.

Masresha Assefa, (2018) conducted study on the Effect of Supply Chain Management Practices on Company Performance. The case of Techno style private limited company. The study showed that, Strategic supplier relationship, the level of information sharing, quality of information sharing and lean practices have medium whereas customer relationship has low relation to company performance with the statistical significant level. Even if the study done by Masresha tried to address the supply chain management practice and areas but focused more of on the financial indicators of organizational performance.

Lina Zewdu,(2017) conduct study on the Effect of Supply Chain Management Practices on Organization Performance in The Case of Ethiopian Agricultural Business Corporation-Agricultural Input Supply. The overall result from the study indicates that effective supply chain management has tremendous effect on the organizational performance of Ethiopian Agricultural Business Corporation-Agricultural Input Supply. Even if the study conducted by Lina tried to address the supply chain management practice but, it fails to incorporate internal lean practice and this effect is not however suitable or true to all supply chain factors.

From exploratory research done by Omainet al. (2010) based on previous studies argued that the implementation set of supply chain management practices vary depending on the country and type of organization involve. Therefore, there is no clear set of supply chain practices suitable for all industries or countries.

However, most of the researches related to the supply chain managements were carried out in developed countries which have different economic, political, technology, social, legal and cultural status. As a result, it may be difficult to directly apply and generalize that the same practices and collaboration as well as problems of supply chain management exists in Ethiopia. This is for the reason that Ethiopia has different Economic, technological, political, social, legal and cultural status than other countries.

Furthermore, different studies from different countries have used similar dimensions when measuring supply chain management practices implementation example: Basnetet al., 2000 (New Zealand); Li, et al.,2006 (USA); Kushwaha and Barman, 2008 (India); Choon Ho 2011 (Malaysia); Adebayo, 2012 (Nigeria); Ardiantoet al., 2013 (Indonesia); Qayyumet al., 2013 (Pakistan); Woldemichael, 2012 (Ethiopia); Mwale, 2014 (Kenya); Mensahet al., 2014 (Ghana); Karimi and Rafiee, 2014 (Iran) just to mention the few, all these studies have indicated to use similar dimensions of supply chain management practices to their particular countries such as strategic supplier relationship, information sharing, outsourcing, customer relationship, lean practices. They indicated positive results to support such practices to be suitable in their respective countries regardless of variation of culture, style of management, geographical background, and ideology, type of industry from one country to another or from one continent to another. Therefore this study supported such fact of more similarities found between two countries in terms of supply chain management practices implementation is more than the differences.

Thus, the researcher would be initiated to conduct this study to fill the knowledge gap of previous study and systematically identify the importance of those factors for better supply chain management practices in Shemu soap and detergent plc located in Dire Dawa City. Considering the above facts in mind this study answered the following research questions to understand the organizations' strategic view and practices on the supply chain management practices.

1. What is the effect of strategic supplier partnership on organizational performance?

2. How does customer relationship affect organizational performance?

3. How does level of Information Sharing affect organizational performance?

4. How does quality of information sharing affect organizational performance?

5. What is the effect of internal lean practice on organizational performance?

\subsection{Objective of the Study}

The general objective of this study is to examine the effect of supply chain management practices on organizational performance in case of Shemu soap and detergent plc Dire Dawa. More specifically the study would address the following specific objectives; 
$>$ To identify the effect of strategic supplier partnership on organizational performance.

$>$ To identify the effect of customer relationship on organizational performance.

$>$ To investigate the effect of level of Information Sharing on organizational performance.

$>$ To examine the effect of quality of information sharing on organizational performance.

$>$ To examine effect of internal lean practice on organizational performance.

\section{Research Methodology}

\subsection{Research Design and Methodology}

The population for this study is comprised of workers in shemu soap and detergent private limited company, found in dire dawa city. This research prompts to explain the kind of relationship between supply chain management practice and organizational performance as well as its impact on organizational performance. Therefore, the research is explanatory research. The study has been carried out in shemu soap and detergent factory p.1.c

\subsection{Method of Data Collection \\ 2.2.1. Data Sources}

In this study both primary and secondary data sources were used. To collect primary data the researcher distributed questionnaires to employees found in shemu soap and detergent factory p.l.c. On the other hand, the researcher collected secondary data from Company reports, previous studies conducted in related topics, books, articles, and journals were used to address and organize the literatures and theoretical frame work of the study. As far as data gathering tools is concerned, the instruments used to collect data were questionnaires. A questionnaire involving closed-ended with scaled items was distributed to employees in the factory.

\subsubsection{Sampling Procedures and Sample Size}

In order to select the sample from the population, the researcher applied stratified probability sampling procedure. The sample taken for this study is assumed to represent offices of each department; the researcher selected the sample from the total population as shown below. For the purpose of questionnaire distribution, 5 employees from finance, 14 from quality, 62 from supply chain, 250 from manufacturing, 39 from human resource and 25 from project which totals 396.

\subsection{Method of Data Analysis}

\subsubsection{Variables and measurement}

The Supply chain management practice variables analyzed involves five different variables i.e. strategic supplier partnership, customer relationship, level of information sharing and quality of information sharing and internal lean practice. The data was analyzed using inferential statistics particularly ordinal logistic regression analysis employed on Statistical Package for Social science (SPSS) output. And performance was measured using Responsiveness, Flexibility, Dependability, Lead time, Quality and Innovativeness.

\subsubsection{Reliability and validity measurement}

According to Yalew Endaweke (2009) reliability and validity of data ready for analysis can be assured by using the triangulation method of data collection using multiple sources of data collection such as interview, document analysis and questionnaire and in terms of the kinds of samples used, using sample size with heterogeneous backgrounds.

\subsubsection{Ordinal Logistic Regression Assumptions}

Since the Ordinal Logistic Regression model has been fitted, now we need to check the assumptions to ensure that it is a valid model. The assumptions of the Ordinal Logistic Regression are as follow and should be tested in order: (Evangeline Lee, 2019)

1. The dependent variables are ordered.

2. One or more of the independent variables are continuous, categorical or ordinal.

3. No multi-collinearity.

4. Proportional odds/ test of parallel line

\subsubsection{Multicollinearity test}

According to Field (2009) cited that Variance Inflation Factor (VIF) value above 10 and a tolerance (1/VIF) value below 0.10 pose a multicollinearity problem. From the below table 1 VIF Value ranges from 1.057 to 3.787. Tolerance value ranges within the value of $0.264-0.946$. In this study, these values (both VIF and tolerance level) indicate that for this analysis, there is no serious multi-collinearity problem. 
Table 1. Multicollinearity Test of Independent Variables

\begin{tabular}{|l|l|l|}
\hline \multirow{2}{*}{ MODEL } & Collinearity Statistics \\
\cline { 2 - 3 } & Tolerance & VIF \\
\hline SSP & .330 & 3.028 \\
\hline CR & .405 & 2.470 \\
\hline LIS & .946 & 1.057 \\
\hline QIS & .264 & 3.787 \\
\hline ILP & .930 & 1.075 \\
\hline
\end{tabular}

Source: researcher survey, (2020)

a. Dependent Variable: OP

\subsubsection{Test of parallel lines}

The proportional odds model assumes that the cumulative logits can be represented as parallel linear functions of independent variables. That is, for each cumulative logit the parameters of the models are the same, except for the intercept. Consequently, according to the proportional odds assumption, odds ratio is the same for all categories of the response variable (Agresti (2002)).

Table 2. Test of parallel lines

\begin{tabular}{|l|l|l|l|l|}
\hline Model & -2 Log Likelihood & Chi-Square & Df & Sig. \\
\hline $\begin{array}{l}\text { Null Hypothesis } \\
\text { General }\end{array}$ & $\begin{array}{l}336.089 \\
334.138^{\mathrm{b}}\end{array}$ & $1.952^{\mathrm{c}}$ & 115 & \\
\hline
\end{tabular}

The null hypothesis states that the location parameters are the same across response categories.

a. Link function: Logit.

Result of test of parallel lines indicates that for the proportional odds assumption appears to have held because the significance of Chi-Square statistics is $1.000>0.05$. So the assumption is satisfied (as $p=1.000$ ) and the model is valid for this data.

\section{Results and Discussion}

\subsection{Introduction}

This study tried to examine the effect of supply chain management practice on organizational performance of shemu soap and detergent factory p.l.c. Descriptive statistics were firstly done with the aim to describe the data (Durrheim, 2002b). Further statistical analyses were then utilized to determine if a statistical association existed between the research variables (Boyle, 2009).

\subsection{Ordinal Logistic Regression Analysis}

Ordinal logistic regression was a type of logistic regression analysis that when the response variable is categorized more than two with having natural order or rank. The model given in the logistic regression model deals with the relationship between the predictor and response variables is not a linear function in logistic regression; instead, the logarithmic transformation of equation yields the linear relationship between the predictor and response variables. The logit transformation of $\mathrm{P}_{\mathrm{i}}$ given as follows:

$\operatorname{logit}\left[\mathrm{P}_{\mathrm{i}}\right]=\beta_{0}+\beta_{1} \mathrm{x}_{1}+\beta_{2} \mathrm{x}_{2}+\cdots+\beta_{\mathrm{r}} \mathrm{x}_{\mathrm{r}}$

Logistic regression is a form of regression, which is used when the dependent variable is dichotomous, such as implemented (when the response is very high, high, and moderate) and not implemented (if the response is low and very low). Under Ordinal Logistic Regression Analysis can be deal about Model Fitting Information, Goodness-of-Fit, Pseudo R-Square, Parameter Estimates and Test of parallel lines.

\subsubsection{Test of parallel lines}

The proportional odds model assumes that the cumulative logits can be represented as parallel linear functions of independent variables. That is, for each cumulative logit the parameters of the models are the same, except for the intercept. Consequently, according to the proportional odds assumption, odds ratio is the same for all categories of the response variable (Agresti (2002)).

\section{Table 3 Test of parallel lines}

\begin{tabular}{|l|l|l|l|l|}
\hline Model & -2 Log Likelihood & Chi-Square & Df & Sig. \\
\hline $\begin{array}{l}\text { Null Hypothesis } \\
\text { General }\end{array}$ & 336.089 & & & \\
& $334.138^{\mathrm{b}}$ & $1.952^{\mathrm{c}}$ & 115 & 1.000 \\
\hline
\end{tabular}

The null hypothesis states that the location parameters are the same across response categories.

a. Link function: Logit.

Result of test of parallel lines indicates that for the proportional odds assumption appears to have held because the significance of Chi-Square statistics is $1.000>0.05$. So the assumption is satisfied (as $p=1.000)$ and 
the model is valid for this data.

\subsubsection{Model Fitting Information}

The researcher compares the final model against the baseline to see whether it has significantly improved the fit to the data. The Model fitting Information table gives the -2 log-likelihood values for the baseline and the final model, and SPSS performs a chi-square to test the difference between the -2LL for the two models given in the following table

Table 4. Model Fitting Information

\begin{tabular}{|l|l|l|l|l|}
\hline Model & -2 Log Likelihood & Chi-Square & Df & Sig. \\
\hline Intercept Only & 438.260 & & & \\
Final & 336.089 & 102.170 & 5 & .000 \\
\hline
\end{tabular}

Link function: Logit.

The Model Fitting Information table, which gives the -2 log likelihood for the intercept only and final models can be used in comparisons of nested models. The statistically significant chi-square statistic $(\boldsymbol{p}<\mathbf{0 . 0 5})$ indicates that the Final model gives a significant improvement over the baseline intercept-only model. This tells us that the model gives better predictions than based on probabilities for the outcome categories.

\subsubsection{Goodness-of-Fit}

The Goodness-of-Fit table contains Pearson's chi-square statistic that are intended to test whether the observed data are consistent with the fitted model. When the $\mathrm{p}$ value is large, its conclude that the data and the model predictions are similar and that the model fit the data well and becoming a good model. However if the assumption of a good fit violated, conventionally if $p<.05$, then the model does not fit the data well.

Table 5. Goodness-of-Fit Statistics

\begin{tabular}{|l|l|l|l|}
\hline & Chi-Square & Df & Sig. \\
\hline Pearson & 1279.941 & 1699 & 1.000 \\
Deviance & 336.089 & 1699 & 1.000 \\
\hline
\end{tabular}

Link function: Logit.

From the Goodness-of-Fit Statistics table the results for analysis suggest the model does fit very well $(\boldsymbol{p}>\mathbf{0 . 0 5})$. The result suggests good model fits. The Goodness-of-Fit test shown in Table 5 explores whether the predicted probabilities are the same as the observed probabilities. An overall goodness of fit of the model is indicated by $\mathrm{p}$-values $>0.05$ (Hosmer and Lemeshow, 2000). From the Goodness-of-Fit Statistics table the results for this analysis suggest by a significance level of 1.000 . Thus the model produced a similarity between the observed and predicted probabilities that indicating a good model fit.

\subsection{Pseudo R-Square}

According to Hosmer and Lemeshow (2000), unlike in linear regression the logistic regression is only used to compare competing models that are used for the same data. A value of 1 is an indication of a perfect fit whilst a value of zero is an indication that there is no relationship. The higher the value the better fit the model.

Table 6. Pseudo R-Square

\begin{tabular}{|l|l|}
\hline Cox and Snell & .758 \\
Nagelkerke & .760 \\
McFadden & .233 \\
\hline
\end{tabular}

Link function: Logit.

The Cox \& Snell R Square and Nagelkerke R Square values provide an indication of the amount of variation in the dependent variable explained by the model (from the minimum level 0 to a maximum of approximately 1). In this case, the two values are 0.758 and 0.760 . The model as a whole explained $75.8 \%$ (Cox \& Snell R Square) and $76 \%$ (Nagelkerke R Square) of the variance of organizational performance (Dependent Variable).

\subsection{Parameter Estimates of Ordinal Logistic Regression}

Parameter estimates tell you how much each independent variables contribute to dependent variable which is organizational performance. 


\begin{tabular}{|c|c|c|c|c|c|c|c|c|c|}
\hline \multirow[b]{2}{*}{ Model } & & \multirow[b]{2}{*}{ Estimate } & \multirow[b]{2}{*}{ Std. Error } & \multirow[b]{2}{*}{ Wald } & \multirow[b]{2}{*}{ Df } & \multirow[b]{2}{*}{ Sig. } & \multirow[t]{2}{*}{$\operatorname{Exp}(\mathrm{B})$} & \multicolumn{2}{|c|}{$90 \%$ Confidence Interval } \\
\hline & & & & & & & & Lower Bound & $\begin{array}{l}\text { Upper } \\
\text { Bound }\end{array}$ \\
\hline $\begin{array}{l}\text { (constant) } \\
\text { Location }\end{array}$ & SSP & $\begin{array}{l}4.67 \\
2.437\end{array}$ & .627 & 15.126 & 1 & .000 & 9.676 & 1.407 & 3.468 \\
\hline & $\mathrm{CR}$ & 1.371 & .493 & 7.722 & 1 & .005 & 7.989 & .559 & 2.182 \\
\hline & LIS & 1.239 & .585 & 4.486 & 1 & .034 & 6.181 & .277 & 2.201 \\
\hline & QIS & 1.392 & .554 & 6.320 & 1 & .012 & 2.232 & .481 & 2.303 \\
\hline & ILP & .108 & .671 & .026 & 1 & .872 & 0.000 & -.995 & 1.211 \\
\hline
\end{tabular}

Source :own survey, 2020

The wald test statistics result for strategic supplier partnership, customer relationship, level of information sharing and quality of information sharing shows a value greater than 1(one) and their P values shows less than 0.05. So those mentioned variables are the significant predictors. Whereas the Wald test statistics result for internal lean practice shows a value of less than 1 (one) and its $\mathrm{P}$ values shows greater than 0.05 . So internal lean practice is not significant predictors.

\section{Conclusions and Recommendations}

\subsection{Conclusion}

Based on the study result, it can concluded that Strategic Supplier Partnership, customer relationship, level of information sharing, quality of information sharing and the organizational performance of Shemu soap and detergent plc are positively related and statistically significant. However, internal lean practice is not statistically significant to influence organizational performance.

However, the general conclusion emerged in this study was that, SCM practices understanding and implementation in Shemu soap and detergent plc can have a direct, positive influence in the organizational performance when effectively and efficiently implemented. The effectiveness of performance depends on the effective management of supply chain management practice.

\subsection{Recommendations}

The findings of this research can be significant indication for workers and managers who take charge of supply chain management practices. In light of the summary of findings and conclusions, the following possible recommendations are recommended as being valuable for improving Supply chain management practices to assure Organizational Performance.

* Much more commitment is required from the workers of the company in order to have best level of information sharing which helps the company to keeps in touch frequently with their trading partners and informs each other about any changes that may affect the other partners and the business processes.

* The company should strengthen on providing accurate, reliable, and timely information to trading partners and get feedback on regular basis. The company should extend the practice of using modern communication technologies used for transfer of information in all areas of the firm. And also should strongly work to bring the best quality of information shared between the workers of the company.

* It's better if the company implementing of manufacturing practices that focused on reduction of waste and Should implement the manufacturing practice that focused on reducing non-value adding activities (those activities didn't any value but consumed resources)

\section{References}

1. Adebayo, I. Toyin. (2012), -- Supply Chain Management (SCM) Practice in Nigeria Today: Impact on SCM performed, European Journal of Business and Social Sciences, Vol. 1.No. 6, pp 107-115.

2. Agresti, (2002). An introduction to categorical data analysis ( $2^{\text {nd }}$ edition.). New York: John Willey.

3. Ardianto, Y. T., Surachman, Salim, U. \&Zain, D. (2013).An empirical internal perceptions study of the implementation supply chain management in Indonesian manufacturing companies as a mediating factor of information technology utilization to organization performances. European Journal of Business and Management, Vol.5, No.16.

4. Basnet, C., Corner, J., Wisner, J. and Tan, KC. (2000) Supply chain management: practice and performance in New Zealand. Department of Management Systems, University of Waikato

5. Boyle, T.A., Scherrer, R.M. (2009), -An empirical examination of the best practices to ensure manufacturing flexibility, Journal of Manufacturing Technology Management, Vol.20, No. 3, pp.348-366.

6. ChoonHo, C. (2011). The influence of supply chain management (SCM) practices on organizational performance: Knowledge management processes a mediator. Master's Degree, UniversitiSains Malaysia.

7. Christopher \&Towill, (2000), international journal of physical distribution and logistics management, Vol. 31, 
No. 4.

8. Christopher, M. (2005), Logistics and Supply Chain Management. Harlow: Prentice Hall.

9. Cousins, et al., 2006.Journal of operations management.

10. Evangeline Lee, (2019). Ordinal regression. Retrieved may 09, 2019. From <https://www.standrews.ac.ac.uk/media/capod/students/mathssupport/ordinar logistics regresion.pdf $>$

11. Fawcett, S., Ellram, L., \& Ogden, J. (2008). Supply Chain Management: From Vision to Implementation. New Jersey: Pearson Practice-Hall.

12. Hailemickael Deres. (2011), - Supply Chain Performance of selected leather Footwear firms in Addis Ababa: School of business \& public administration masters of business Programl.

13. Hosmer, D and Lemeshew, S, (2000). Applied logistics regression. New York:Wiley.

14. Hosmer, D andLemeshew, S, (2000). Applied logistics regression. New York: Wiley.

15.Karimi, E.and Rafiee, M. (2014).Analyzing the impact of supply chain management practices on organizational performance through competitive priorities (case study: Iran pumps company). International Journal of Academic Research in Accounting, Vol. 4, No. 1

16. Kothari, C.R. (2004). Quantitative Techniques. New Delhi, Vikas Publishing House Pvt. Ltd., p.64, 1978.

17. Kushwaha and Barman, (2008).Impact of supply chain quality management on competitive advantage and organizational performance.

18. Li, S., Ragu-Nathan, B., Ragu-Nathan, T. S. and Rao, S.S. (2006). The impact of supply chain management practices on competitive advantage and organizational performance. The International Journal of Management Science, 34: 107-124.

19. LinaZewdu,(2017) conduct study on the Effect of Supply Chain Management Practices on Organization Performance in The Case of Ethiopian Agricultural Business Corporation-Agricultural Input Supply.

20. Makena Naomi Mutuerandu (2014), _-Impact of Supply Chain Management Practices on Organizational Performance: A Case Study of Haco Industries Limited (Kenya) \|, IOSR Journal of Business and Management (IOSR-JBM) Volume 16, PP 62-64

21. MamunHabib 2011, „Supply Chain Management (SCM): Theory and Evolution ${ }^{\text {ee }}$, Supply Chain Management - Applications and Simulations. Prof. Dr. Md. MamunHabib (Ed.), ISBN: 978-953-307-250-0,

22. Margaret Rouse whatls.com, 2008, slide share.

23. Masresha Assefa, (2018) conducted study on the Effect of Supply Chain Management Practices on Company Performance. The case of Techno style private limited company.

24. Mensah, C., Diyuoh, D. and Oppong, D. (2014).Assessment of supply chain management practices and its effects on the performance of Kasapreko Company Limited in Ghana.European Journal of Logistics Purchasing and Supply Chain Management, Vol.2, No. 1, pp.1- 16.

25. Mwale Hilda. (2014), - supply chain management practices and organizational performance of large manufacturing firms in Nairobi, Kenyall.

26. Omain, S. Z., Abdul Hamid, A., Abdul Rahim, A. and MdSalleh, N. (2010).Supply chain management practices in Malaysia palm oil industry. A paper presented at the 11thAsia Pacific Industrial Engineering and Management Systems Conference (APIEM), Melaka.

27. Qayyum, M. N., Ali, M. and Shazad, K. (2013). The impact of supply chain management practices on the financial performance of the organization. International Journal of Operations and Logistics Management Vol. 2, No. 2, Pg. 22-40

28. Stecke and Kumar, 2007, journal of marketing channels. Vol. 16.

29. Vincent kipropkimechwa (2015), Impact of Supply chain Management Practices on the Performance of Banks in Kenya: A case of Post bank: International Journal of Computer Applications Technology and Research.

30. Woldemichael, D. A. (2012), The impact of supply chain management practices on the organizational performance of basic metal and engineering industries in Ethiopiall. Master's Degree, University of South Africa.

31.Zigiaris 2000, Report produced for the EC funded project, INNOREGIO: dissemination of innovation and knowledge management techniques. MSc, BPR engineer Sotiris Zigiaris, 